This is the uncorrected version of the article published subsequently as:

Tennhoff, Wiebke; Nentwich, Julia C.; Vogt, Franziska (2015). Doing gender and professionalism: Exploring the intersectionalities of gender and professionalization in early childhood education. In: European Early Childhood Education Research Journal, Volume 23, Issue 3, Pages 340 - 350.

\title{
Doing Gender and Professionalism: Exploring the Intersectionalities of Gender and Professionalization in Early Childhood Education
}

\author{
Wiebke Tennhoff ${ }^{1 a}$, Julia C. Nentwich ${ }^{a}$, Franziska Vogt $^{b}$
}

\begin{abstract}
${ }^{a}$ Research Institute for Organizational Psychology, University of St. Gallen, Switzerland ${ }^{\mathrm{b}}$ Institute of research in teaching and learning, University of Teacher Education, St. Gallen, Switzerland
\end{abstract}

\begin{abstract}
Men in Early Childhood Education are subjected to different discourses: while they are facing serious mistrust on the one hand, their otherness to the field is also interpreted as new and potentially innovative on the other hand. This article explores how male childcare workers create and take up different subject positions by drawing on these competing discourses in order to acquire a legitimate position as men in the female-dominated context of Swiss day care centers. In constructing themselves as professionals they create a subject position that seems to move beyond the gender binary. Analyzing the position of the professional in depth, the article first shows how this position is accomplished and then explores how gender unfolds between the lines by infusing professionalism with masculinity.
\end{abstract}

Keywords: discourse analysis; professionalism; subject positions; gender; masculinity

\section{Introduction}

As Switzerland is a federalist state, Early Childhood Education (ECE) systems differ across the country and childcare paradigms differ according to the three main language areas ${ }^{2}$. The ECE provision encompasses two different structures the "Kindertagesstätte (Kita) or Krippe",3

\footnotetext{
${ }^{1}$ Corresponding author. E-Mail: wiebke.tennhoff@unisg.ch

${ }^{2}$ The German speaking regions refer to Fröbel or Pestalozzi, thereby claiming a holistic view on children's development, the French speaking part of Switzerland pursues a cognitive oriented pedagogy based on Piaget and the Italian speaking part often brings in Montessori (Stamm et al. 2009, 34).
}

${ }^{3}$ Child day care center or nursery; Structures d'accueil collectif de jour or crèches/Strutture di custodiacollettiva diurne. 
and the "Kindergarten". The Kita (in the following: day care centre) provides places for children from three months onwards. The kindergarten starts in most cantons at four years and forms a part of the educational system, mostly compulsory and free of charge. In this manner, the ECE system falls into an education-oriented and a care-oriented part. This also affects its societal status. The majority of childcare in Switzerland is provided within the family, mostly by grandparents and other relatives whereas only $38.8 \%$ of children under the age of four attended centre-based care in 2013 (SFSO 2014; Nentwich, Tennhoff, and Schälin forthcoming). Public discussions concentrate on care aspects of day care centres by highlighting its use for working mothers while silencing education-related befits for children (Stamm 2009, 47). The historical heritage of day care centres as "the legitimate child of the industrialization" becomes apparent (Grob-Menges 2009, 75).

This division also holds true for the educational level of the staff working in ECE. Whereas child care workers complete three years of vocational training, kindergarten teachers hold a Bachelor's degree. ${ }^{4}$ In recent years, however, the role of day care centres as facilitating early childhood development and learning has slightly gained more public attention (Ermert Kaufmann et al. 2008). These recent developments also mark the starting point for debates about the quality of childcare which has led to an expanding interest for quality labels and further qualification of the staff (Vogt forthcoming) The debate about professionalism of day care centres also affects discourses about the sex of the staff and the gender of the occupation respectively.

\section{Men in Early Childhood Education - the "wanted" and the "unwanted Other"}

From a historical perspective, working in ECE is closely connected to mothering and femininity. In the course of the industrial revolution childcare institutions were founded with the objective of providing shelter for children of working class families whose mothers had to work for economic reasons. In the late ninetieth century, the women's movement claimed that caring as a natural duty of women should be expanded to the social level. This idea of women as bearer of "spiritual motherlineness" (Rendtorff 2006, 37, translated by the authors) opened possibilities for participation in this area of labor market - although the emancipatory idea remained ambiguous (EKF 2009a; EKF 2009b).

\footnotetext{
${ }^{4}$ The difference also finds its expression in the occupational titel: "Fachperson Betreuung" ("specialist care") highlights care aspects of the job, "Lehrperson für Kindergarten" (kindergarten teacher) highlights educational aspects.
} 
Since then, there have been dominant discourses constructing ECE as being "women's work" (Rabe-Kleberg 2003). The results of our research project "Dolls, building blocks and outdoor activities: (un)doing gender in the nursery" show that gender is inscribed in the selection and arrangement of materials and spaces as (Vogt, Nentwich, and Tennhoff forthcoming) well as in the daily structures and routines (Nentwich, Vogt, and Tennhoff forthcoming). The organization of daily work in day care centers reflects images of childcare that are compounded with the ideal of the housewife and mother. Activities and materials that are associated with masculinity, such as for instance, physical activities, loud and noisy play or wood work, as well as masculine accessories in the role play corner are underrepresented. Moreover, the time structure of the day is often set by the needs of the household and of home making like preparing and serving food, cleaning the rooms etc. (Nentwich, Vogt, and Tennhoff, forthcoming). Since day care centers are perceived as a "female arena" the professional status of the occupation is rather low (Rabe-Kleberg 2003, 64). All these aspects hinder the entrance of men in the field. Only $2 \%$ of Swiss child care workers are male (OECD 2012). . $^{5}$

As the dominant discourse constructs the image of the "ideal worker" as feminine, men might struggle with being perceived as not fitting in. Applying the stereotypical perception of the "teaching woman" and the "administrating man" parents are often surprised to see men working with young children (Sargent 2005, 255f.). As it is assumed that men are by nature less interested in childcare, their motivation for being with children is constructed as potentially misled and sexual. Often they are viewed as being ill motivated and confronted with the suspicion of being pedophiles (Buschmeyer 2013; Cremers and Krabel 2012). In this manner, men represent danger, while women embody motherly love, or, as an interviewee in Sargent's $(2005,254)$ study puts it: “Women's laps are places of love. Men's are places of danger."

However, recently the high percentage of women in teaching professions as compared to the few men is being referred to as problematic. Especially since international comparisons such as PISA highlighted boys' achievement gap particularly regarding their reading skills, it is also claimed that boys might suffer from the feminization of the teaching profession - a claim strongly contested within the research community (Faulstich-Wieland 2011; Kappler, Keck

\footnotetext{
${ }^{5}$ Data from 2010, only public institutions were considered.
} 
Frei, and Bieri Buschor 2012; Rieske 2011). Current efforts focus on increasing the participation of men in ECE. Researchers as well as political institution argue in favor of more male childcare workers, for an overview of arguments see Peeters (2013).

In general, discourses of the "feminization of education" (Faulstich-Wieland 2011; RabeKleberg 2005; Rohrmann 2009) depict women as not being able to meet the needs and interests of boys in a satisfactory way, and interpret the lack of men as problematic. In this manner, men's otherness to the field is interpreted as something new and potentially innovative in the female-dominated context, and masculinity becomes highly valued (Faulstich-Wieland 2011). These discourses call for the entrance of men as bearer of special competences that are missing in ECE. Men as "the other" are being viewed as being able to contribute something other than women and thus being able not only to meet the boys needs, but also - through innovation and special competencies to promote professionalization - of the field in general. Hence, although the professionalization of the field and the employment of men could be considered as two independent topics (Cameron 2012), there is an inherent linking of professionalism and masculinity in the discourses focusing on men in ECE so that "the existence of male staff is already interpreted as a sign of innovation, a symbol of progressiveness of the institution" (Breitenbach and Bürmann 2014, 51, translated by the authors).

To summarize it can be noted that two opposed and conflicting threads dominate the discourse about gender and ECE: First, the emphasis on women's "natural ability" to care for children and the insinuation of men as being dangerous, which constructs men as the "unwanted other" in the field of ECE. Second, men as the "wanted other" as a consequence of problematizing the dominance of women and the attribution of special competences to men, which are considered as urgently needed in day care centers. Both discourses strongly rely on gender differences, assuming men and women to have different and even opposed competences. Therefore, even today, men's position in the field of ECE is far beyond selfevident. Men entering the field are faced with expectations of "extra qualities" on the one hand and at the same time have to fight suspicions.

In this article we explore how male childcare worker deal with the situation of being positioned as the "wanted" and the "unwanted other" by using the theoretical concepts of subject positions and discursive strategies (see also Nentwich et al. 2013). Which subject 
positions are offered by discourses and how do our interviewees engage with them? In such a perspective, the discourse of professionalism becomes relevant as a source for acquiring legitimacy. Furthermore, we discuss the paradoxical effects of the implicit link established between femininity and ECE. The paper is organized as follows: after presenting our methodological approach, we give an overview of our empirical finding. We then present an in-depth analysis of the subject position of the "professional" based on two interviews and discuss our findings in the light of the discourse of professionalization.

\section{Methodology}

The interviews were conducted as part of the research project "Dolls, building blocks and outdoor activity days: (un)doing gender in the nursery". The three year project was funded by the Swiss National Foundation within the National Research Programme NRP 60 tackling issues of gender equality in Switzerland. The empirical research took part in Switzerland's German-speaking part. The overall interest was the investigation of (un)doing gender in day care centers. ${ }^{6}$ As part of this research project we conducted semi structured interviews with ten male and eight female day care workers working alongside each other in ten nurseries. Different sampling criteria were relevant: first, we identified day care centres in the Germanspeaking part of Switzerland who employed fully trained male childcare workers. These men had to have completed a vocational training programme as a childcare worker. Second, they had to be working with a female colleague, who, ideally, was working there before the man became part of the team. Thereby, organizational changes that could potentially have occurred (as suggested by the discourses outlined above) could have been experienced and recalled (Gherardi and Poggio 2007). Topics covered include the interviewee's way into the occupation and the entrance into the organization, daily practices of organizing, sharing, and negotiating work amongst the colleagues and individual preferences concerning pedagogical activities. After being digitally recorded, the interviews have been transcribed verbatim including the notion of non-verbal expressions such as laughter, pauses and ruptures.

Our theoretical starting point is a performative view on masculinity and femininity and thus the fluid and flexible aspects of practicing gender (Nentwich and Kelan 2014). Given the assumption that masculinity and femininity are not fixed and stable concepts but shifting with contexts, we focus in our analysis on the subject positions that were made relevant in the interviews and taken up or set aside by the interviewees. We used discursive psychology

\footnotetext{
${ }^{6}$ For more information on the project and the NRP 60 please visit www.nrp60.ch.
} 
(Edley and Wetherell 1997; Davies and Harré 1990) as well as the concept of (un)doing gender (West and Zimmerman 1987, Deutsch 2007) as theoretical framework, and analysed how our interviewees position themselves as male childcare workers. The concept of subject positioning rests on Foucault's notion that discourses "form the objects of which they speak" (Foucault 1972, 39) and was further developed in the context of gender and identity theory (Butler 1990) as it proved helpful to theorize identity as a discursive construct (Galasin'ska and Galasin’ski 2003). In this paper, we understand subject positions as locations in discourses that are brought up by the interviewees in order to construct themselves as intelligible persons (Butler 1990; Davies and Harré 1990). Discourse theory directs the attention to the paradoxical relationship between discourses and the speaking subject. That is, the subject is constructed by discourses and has to cite them but has also a certain degree of freedom to choose between different subject positions. Thus, subjects can be understood as „the masters and the slaves” of discourses (Edley 2001, 190). Discursive strategies play a crucial role in the constitution of subjectivity (Wetherell and Edley 1999). In our analysis, we see discursive strategies as the attempt of the subject to create a subject position that, necessarily, is gendered (Butler 1990). (Un) doing gender in our reading is the putting forward of gender differences or sameness (Deutsch 2007) when engaging in different discursive strategies.

Conducting a discourse analysis, we first coded the interviews using atlas.ti relating to our broader research questions. Thereby we categorized sequences as "doing gender differences" (for example when the interviewee attributes special competencies to himself due to his sex category) and "doing gender sameness" (for example when shared abilities or goals are highlighted). In a second reading, we analysed all sequences in-depth, where the male childcare worker is positioning himself as a male childcare worker or where the female colleagues are commenting about the male childcare worker. We watched out for hints of discourses about femininity and masculinity and ECE. The focus lies on sequences which refer to culturally available stories for sense-making and narratives about motives and emotions (Wetherell and Edley 1999, 338; Nentwich et al. 2013). Six subject positions were found that the interviewees engage in in order to explain their presence in the female dominated field. The next section provides a rough overview (for a detailed analysis see also Nentwich et al. 2013).

\section{Empirical Findings}


In order to construct a legitimate position, that is a position that allows male childcare workers to bridge the gap between their gender and the female connotation of their occupation, six subject positions can be identified. Three of the subject positions emphasise gender difference, two explicitly put forward sameness and the sixth subject positon moves beyond this binary structure.

The first subject position emphasizing difference is that of the "male niches". This subject position is constructed by stressing the relevance of stereotypical masculine skills and interests such as playing football or engaging in rough and tumble play. With the second subject position, men are speaking of themselves as being in a father's position. Thereby they associate ECE settings with a family and reference a legitimate position in it - and hence an important relationship with children. The third subject position is the "male breadwinner". When constructing and taking this position, men emphasize their position in the hierarchy of the institution, or refer to the importance of concepts of career and breadwinning. In emphasizing difference, men highlight positive aspects of being "the other" in order to achieve a legitimate position, meanwhile actively avoiding the highly negative and hence dangerous "non-position" of the pedophile that is implied in discourses constructing men as the "unwanted other". The men also refer to discourses of gender sameness. Here we found two subject positions which we named "the equal" and "the feminine". Here, equal rights and the importance of equality in the team are highlighted. Taking the subject position "the feminine", men mention skills and interests that are generally depicted as feminine and claim them as appropriate and suitable for themselves; by doing so they solve the dissonance between their gender and the female connoted occupation. The final subject position seems to move beyond this binary structure of either emphasizing difference or sameness. Here, becoming or being a professional is emphasized by referring to professional skills and competences. This subject position is analysed more closely in this paper. Our in-depth analysis of the professional's subject position shows that several discursive strategies are used in order to acquire this position and reveals their potential for constructing masculinity at the same time.

\section{Becoming the Professional}

In the course of the interviews, the men switch between several subject positions. However, differences can be found. The younger interviewees frequently refer to a variety of subject positions, whereas the two eldest interviewees Reto and Paul constantly refer to the subject 
position of the professional. Subsequently, we are analysing these two cases in more detail. Both childcare workers appropriate the subject position of the professional by using the same discursive strategies. We distinguish the discursive strategies as follows: "pedagogy and philosophy", "job presentation", "avant-garde” and "agency".

\section{Strategy "Avant-garde”}

When presenting themselves as a professional, both, Reto and Paul, point to their pioneering role. They are in their forties, and have long work experience. In the following example, Reto emphasises his competence in arranging the spatial setting for the children, and recalls how his ideas where taken up by the others:

Reto: ...I prepare the setting outside, what is nice is that the female apprentices now come and say „Look, Reto, we re-arranged the setting” and I realize that the first inputs that I gave back then were laughed at and [whistling] "he has bats in his belfry, he has no clue anyway" Ehm, I realize now that slowly it comes back [...].

Whereas his ideas were not taken seriously in the beginning, they are now taken up by younger childcare workers. Here, Reto emphasises that his pedagogy appeals to his colleagues and therefore are of pedagogical relevance. Furthermore, he lets us know that he, as being a professional, anticipated pedagogical trends ahead of the times. He thus puts himself in the position of an avant-garde educator and turns the position of "the other" that he potentially occupies due to his sex, in something that is associated positively. Immanent to the logic of presenting oneself as avant-garde is the idea of independence. He represents himself as someone developing new approaches instead of following the ideas of others. Thus the reference to general images of gender differences or sameness seems inadequate in this context. Still the position is far from ordinary. It constructs him as somehow superior to other colleagues and emphasises his strength and autonomy. In this manner, the subject position of the professional also carries facets of rebellion and individuality which contributes to values of masculinity, namely, autonomy and independence. Also the next strategy takes the autonomy of the individual as a starting point.

\section{Strategy “Agency"}

Paul talks about his job interview for his position in the new day care centre. He was asked to begin his new job while still working in another day care centre which he refused to do: 
Paul: [...] At first there was the idea that I would change job before the probation period ended. But then I said: Wait, they will have a problem then! And the children and the group they need to have a good process ending as well. And that is why I also blocked a bit. I think the goal was to stabilize and calm down the situation. That would have been the idea from my side.

Here, Paul presents himself as an advocate for children's needs and interests. Furthermore, he stresses goals and motives and claims the position of the professional who has legitimate reasons and intentions. The interesting part here is that although he is in a job interview and therefore not in a powerful position as such, he recalls how he intervened when he was meant to change the job too quickly. That he "blocked" the process of hiring (meaning that he argued against it) not only underlines his professionalism (that is, his awareness of the children's needs) but also emphasises his autonomy, power and ability to do so. Speaking of oneself as agentic lacks the necessity to refer to gender differences or sameness since the point of reference is the individual himself or herself. Therefore, there is no need to compare oneself to others. But still, being agentic, having power and reaching one's goal is associated as being a masculine characteristic and thereby serves to construct the position of the professional as masculine.

\section{Strategy "Pedagogy and Philosophy"}

Reto got a special qualification for outdoor pedagogy in addition to his professional childcare worker qualification. He leads a group with an emphasis on outdoor experiences. In the following interview excerpt, Reto explains his way of working with children:

Reto: To me on the one hand it is about nature, and on the other hand I also have a building site for fostering movement. ... Well I do not even take nails out of the way here, that the children will do, and with the building site, that is to me a social building site, a life building site, they build themselves, and they need all imagination when they build something. They have to negotiate with each other, they have conflicts and they need to solve them and also have to explore, and then they discover static, and heavy, long, short, colours, materials and they build something and they are responsible for themselves, what they build ...they can feel that and that is very important for me.

Reto's pedagogy relies on certain pedagogical beliefs. To put his pedagogy into practice he uses special equipment (building site) but also an approach to early education (the children 
will learn to take care) that clearly separates him from the more traditional approaches emphasising caring and protecting the child which are dominant in Swiss nurseries (Nentwich, Vogt, and Tennhoff, forthcoming). Here, he manages to construct himself as a competent professional by naming his pedagogical approach and by stating the intended learning effects in a way that fits with an image of the child as being self-dependent and competent. He is thus able to claim a subject position as a professional who is legitimating his professional action with his professional knowledge and beliefs. Also his way of working seems to represent his pedagogy, a pedagogy connected to metaphorical dimensions ("social building site", "life building site"). In the remainder of the interview, Reto refers to his pedagogy repeatedly and connects his work closely to himself as a person. Thereby he distances himself from the rest of the female staff. As we see, although engaging in the strategy "pedagogy and philosophy” does not rely on gender differences per se, it can be used to distance oneself from the (female) colleagues by claiming an outstanding position for oneself.

\section{Strategy “Job Presentation”}

In the next quote we see Paul recalling the parent's reaction on him joining the day care centre. Here he not only refers to his outstanding position as the deputy leader, but he also emphasises that he worked very hard and long hours.

Paul: And they saw something is happening now. A great, passionate deputy, does the early morning duty and is still often here at six o'clock in the evening, often works 12 hours. And therefore there has always been a positive feedback from the parents. Or I realize these moments, when you come to total depth to really basic topics in parent - teacher meeting, they talk about their life stories, tales of woe and you try to develop a strategy how they could get out of the spiral. For me, these are the really cool and intensive moments.

Here, Paul describes his work in the style of psychological issues ("total depth", developing strategies to get out of the spiral). He thereby not only extends his scope of responsibility but also claims terms and competencies from a profession which is higher in status than the occupation of childcare work. Paul manages to construct his job as demanding and important not only in terms of his formal position as deputy, but also with regards to the content of his responsibilities. As an effect, he is able to adopt an outstanding position within the team that separates him from the "normal" team members. He also emphasizes the demanding aspects of the job, thereby presenting his work in a way that it loses its female connotation of being 
soft and easy. He is thus able to dissolve the contradiction between his gender identity and the gender stereotype of job without naming or relying on gender differences. But since working hard and working long hours is associated with the ideal of hegemonic masculinity, he constructs himself in line of what Wetherell and Edley (1999) term "heroic positions". In this way, he occupies a legitimate position in the nursery and constructs himself as masculine at the same time. Presenting the job as demanding or important on a societal level enables men to assess the job as a "serious" profession. They are thus able to counter the established discourse of childcare being a "semi-profession" (Etzioni 1969; Rabe-Kleberg 2003).

\section{Conclusion}

\section{Counteracting the "unwanted Other"}

Drawing on the subject position of "the professional" neither gender differences nor gender sameness is emphasized. Hence, one could argue that this position is potentially open to both men and women and gender neutral. Claiming this position creates legitimacy for the speaker in a way, that counteracts the difference discourse. Becoming "the professional" does not construct men as the "unwanted other" as gender is not explicitly cited and reinforced. Claiming the subject position of the professional has a protective character: men are able to protect themselves from the potential mistrust by engaging in the subject position of the professional.

\section{Negotiating Gender and Professionalism}

The analysis shows how the construction of masculinity and professionalism are intertwined. While the position of the professional moves beyond the simple binary of being either different or equal and thus seems to prepare a common ground for both women and men in the field, it is not exactly gender neutral. Gender is relevant here, although in a more subtle manner. The way the interviewees interpret the subject position, it also serves as a source of constructing a masculine subject position that overall relies on gender differences or hegemonic forms of masculinity. Hegemonic masculinity is commonly associated with dominant behaviour (Wetherell and Edley 1999) and although the position of the professional can serve as an alternative form of masculinity, it also contains the potential for hegemonic positioning.

Apparently, the link between femininity and ECE affects men's position in ECE in paradoxical ways. While it is mostly argued that a "gender-specific interpretation of professionalism" restricts the entrance of men to the field (Peeters 2013, 124), our analysis 
shows that by the way in which men in the field engage with these discourses they can also serve as a source for stabilizing their position.

As these discourses construct men as the "wanted other" their presence in the field becomes legitimate. On this basis, by claiming the subject position of the professional for instance by pointing to their pedagogical style, their avant-garde status or agency, or by assessing the job as very demanding, men are able to construct and take up a position that resolves the conflict between gender identity and the female connotation of the job. Moreover, their minority status is reframed and masculinity becomes a resource (Breitenbach and Bürmann 2014). Thus, the discourses of the feminization of education and of the professionalization of ECE indeed facilitate the entrance of men to the field.

However, this does not mean that it facilitates gender equality at once. The link between professionalism and masculinity renders professionalization a masculine project. It carries the danger of the implicit degradation of femininity. In this manner, these discourses serve as a blue-print to construct masculinity superior to femininity and facilitate the inclusion of men as the "professional other". In this regard it is important to consider that the connection between masculinity and professionalism is inherent to a broader understanding of professionalism as being male (Rendtorff 2006, 149; Weinbach 2004, 138ff.). Hence, the discourse of professionalism as it is used by our interviewees is not a question of the individual but of the current construction of masculinity that is cited by them.

As an implication for the ECE practices, we follow Cameron's (2012) argument and suggest to separate the question of professionalization from that of the employment of men. Even though employing a male childcare worker can be an important step towards gender equality in ECE this does not necessarily impact on professionalization. The call for professionalization in ECE often problematizes women's overrepresentation in the profession, the current organization of work in daycare centers should over all be addressed in reflecting on questions such as: What kinds of activities are offered to the children? What images of masculinity and femininity are mirrored in these activities? The reflection and diversification of the everyday practices of childcare workers can be considered as an important step of professionalization, which includes both, men and women working in childcare. 
Concerning the aim of increasing the number of men working in the profession, it seems relevant to examine if and how the position of the "unwanted other" still influences the process of choosing the occupation or avoiding it. In this context, daycare centers should consider whether their hiring politics privilege women. Nevertheless, promoting the inclusion of men and meeting them with the expectation of bringing in aspects which are seen as lacking and considered masculine (e.g. playing football or doing rough and tumble play) with the hope of renewing the field of ECE at the same time doesn't seem to be a solution either. In fact, this strategy not only diminishes the female childcare worker's effort in professionalizing the field but also presents a stereotypical image of masculinity.

\section{References}

Breitenbach, E., and I. Bürmann. 2014. Heilsbringer oder Erlösungssucher? Befunde und Thesen zur Problematik von Männern in frühpädagogischen Institutionen. In Jahrbuch Frauen- und Geschlechterforschung in der Erziehungswissenschaft, Männlichkeiten Geschlechterkonstruktion in pädagogischen Institutionen edited by Budde, J, C. Thon and K. Walgenbach, 51-66. Opladen: Barbara Budrich Verlag.

Buschmeyer, A. 2013. Zwischen Vorbild und Verdacht. Wie Männer im Erzieherberuf Männlichkeit konstruieren. Wiesbaden: Springer.

Butler, J. 1990. Gender Trouble: Feminism and the Subversion of Identity. New York: Routledge.

Cameron, C. 2012. Neu betrachtet - Männer und Professionalität in der Kinderbetreuung. In Männer in Kitas, edited by Koordinationsstelle „Männer in Kitas“, 329-348. Opladen, Berlin, Toronto: Verlag Barbara Budrich.

Cremers, M., and J. Krabel. 2012. Generalverdacht und sexueller Missbrauch in Kitas: Bestandsanalyse und Bausteine für ein Schutzkonzept. In Männer in Kitas, edited by Koordinationsstelle „Männer in Kitas“, 265-285. Opladen, Berlin, Toronto: Verlag Barbara Budrich.

Davies, B., and R. Harré. 1990. Positioning: The Discursive Production of Selves. Journal for the Theory of Social Behavior 20 (1): 43-63.

Deutsch, F. M. 2007. Undoing Gender. Gender \& Society 21 (1): 106-127.

Edley, N., and M. Wetherell. 1997. Jockeying for Position: The Construction of Masculine Identities. Discourse \& Society 8 (2): 203-217. 
Edley, N. 2001. Analysing masculinity: interpretatative repertoires, subject positions and ideological dilemmas, In Discourse as Data: a Guide to Analysis, edited by M. Wetherell, S. Taylor, and S. Yates, 189-228. London: Sage and the Open University.

Etzioni, A. (ed.) 1969. The Semi-Professions and their Organisation. New York: Free Press.

Eidgenössische Kommission für Frauenfragen EKF. 2009a. Frauen Macht Geschichte 18482000: Die Frauenbewegung von ihren Anfängen bis zum Ersten Weltkrieg. (http://www.ekf.admin.ch/dokumentation/00444/00517/index.html?lang=de\#sprungm $\underline{\left.\operatorname{arke} 0 \_0\right)}$

Eidgenössische Kommission für Frauenfragen EKF. 2009b. Frauen Macht Geschichte 18482000: Berufsbildung von Frauen. (http://www.ekf.admin.ch/dokumentation/00444/00517/index.html?lang=de\#sprungm $\underline{\left.\operatorname{arke} 0 \_0\right)}$

Ermert Kaufmann, C., Knupfer, C., Krummenacher, J, Marti, V., Simoni, H., and K. B. Zatti. 2008. Familien- und schulergänzende Kinderbetreuung Eine Bestandesaufnahme der Eidg. Koordinationskommission für Familienfragen EKFF. Bern: BBL, Vertrieb Publikationen.

Faulstich-Wieland, H. 2011. Werden tatsächlich Männer gebraucht, um Bildungsungleichheiten (von Jungen) abzubauen? In Geschlechtsspezifische Bildungsungleichheiten, edited by A. Hadjar, 393-415. Wiesbaden: VS Verlag für Sozialwissenschaften.

Foucault, M. 1972. The Archaeology of Knowledge. London: Tavistock.

Galasin`ska, A. and D. Galasin’ski. 2003. Discursive strategies for coping with sensitive topics of the Other. Journal of Ethnic and Migration Studies 29 (5): 849-863.

Gherardi, S., and B. Poggio. 2007. Gendertelling in Organizations. Narratives from Maledominated Environments. Fredriksberg: Liber: Copenhagen Business School Press.

Grob-Menges, U. 2009. 100 Jahre Kinderbetreuung - und stets am Anfang. In Familienergänzende Betreuung, Erziehung und Bildung von Kindern - ein Generationenprojekt in privater und staatlicher Verantwortung, edited by Schweizerische Akademie der Geistes- und Sozialwissenschaften, 75-82. Bern: Schweizerische Akademie der Geistes- und Sozialwissenschaften.

Kappler, C., A. Keck Frei, and C. Bieri Buschor. 2012. "Männliche Lehrpersonen sind äußerst wichtig, aber diese Überlegung war kein Grund für meine Berufswahl“ - Eine qualitative Studie zur Bedeutung von Geschlecht bei der Berufswahl von angehenden Lehrern. Schulpädagogik heute 5 (3) 
Nentwich, J. C., and E. Kelan. 2014. Towards a topology of 'doing gender': An analysis of empirical research and its challenges. Gender, Work and Organization 21 (2): 121134.

Nentwich, J. C., W. Poppen, S. Schälin, and F. Vogt. 2013. The same and the other: Male childcare workers managing identity dissonance. IRS, International Review of Sociology 23 (2): 325-344.

Nentwich, J. C., F. Vogt, and W. Tennhoff. forthcoming. Care and education? Exploring the gendered rhythms and routines of childcare work. In Gender equality in context: policies and practices in Switzerland, edited by B. Liebig, B. Sauer, and K Gottschall. Opladen, Berlin, Toronto: Verlag Barbara Budrich.

Nentwich, J. C., W. Tennhoff, and S. Schälin. forthcoming. Switzerland: "Leitmotif: Sharing! $3+3+1$." In Equally shared parenthood: A global perspective, edited by F. Deutsch.

OECD. 2012. Education at a Glance. OECD Indicators. Paris: OECD Publishing.

Peeters, J. 2013. Towards a gender neutral interpretation of professionalism in ECEC. Revista Espanola de Educacion Comparada. La Educacion Infantil en Perspectiva Europea ano 2013 21: 119-143.

Rabe-Kleberg, U. 2003. Gender Mainstreaming und Kindergarten. Weinheim: Beltz.

Rabe-Kleberg, U. 2005. Feminisierung der Erziehung von Kindern. Chancen oder Gefahren für die Bildungsprozesse von Mädchen und Jungen? In Entwicklungspotenziale institutioneller Angebote im Elementarbereich (Materialien zum Zwölften Kinder- und Jugendbericht, Bd. 2), edited by P. Pasternack, A. Schildberg, U. Rabe-Kleberg, K. Bock-Famulla, and F. Larrám, 135-171. München: Verlag Deutsches Jugendinstitut.

Rendtorff, B. 2006. Erziehung und Geschlecht. Eine Einführung. Stuttgart: W. Kohlhammer.

Rieske, T. V. 2011. Bildung von Geschlecht zur Diskussion um Jungenbenachteiligung und Feminisierung in deutschen Bildungsinstitutionen. Frankfurt, M.: GEW.

Rohrmann, T. 2009. Gender in Kindertageseinrichtungen. Ein Überblick über den Forschungsstand. München: Deutsches Jugendinstitut.

Sargent, P. 2005. The Gendering of Men in Early Childhood Education. Sex Roles 52 (3/4): 251-259

Stamm, M. 2009. Zur Wirksamkeit familienergänzender Kinderbetreuung: Erkenntnisse aus der Forschung und bildungspolitische Folgerungen. In Familienergänzende Betreuung, Erziehung und Bildung von Kindern - ein Generationenprojekt in privater und staatlicher Verantwortung, edited by Schweizerische Akademie der Geistes- und 
Sozialwissenschaften, 47-56. Bern: Schweizerische Akademie der Geistes- und Sozialwissenschaften.

Stamm, M., V. Reinwand, K. Burger, K. Schmid, M. Viehauser, and V. Muheim. 2009. Frühkindliche Bildung in der Schweiz. Eine Grundlagenstudie im Auftrag der Schweizer UNESCO-Kommission, Department für Erziehungswissenschaften. http://www.fruehkindliche-

bildung.ch/fileadmin/documents/forschung/Grundlagenstudie_FBBE_-

_Finalversion_edit_13032009_.pdf (10.01.14)

Swiss Federal Statistical Office SFSO. 2014. Families, households - Data, indicators demand. http://www.bfs.admin.ch/bfs/portal/en/index/themen/01/04/blank/key/04/01.html (07.01.2015).

Vogt, F. forthcoming. Bildung in der frühen Kindheit: ,Bildung und ,pädagogische Qualität‘ als Auslöser von Angebotsausbau und Innovation. In Qualität in der Bildung, edited by M. Bergman, H. U. Grunder, S. Hupka-Brunner, and Ch. Imdorf, 13-28. Bad Heilbrunn: Klinkhardt.

Vogt, F., J. C. Nentwich, and W. Tennhoff. forthcoming. Puppenecken und Bauecken: Gender und Raumordnung. In Perspektiven und Potenziale der Schuleingangsstufe, edited by C. Müller, L. Amberg, T. Dütsch, F. Vogt, and E. Wannack. Münster: Waxmann.

Weinbach, C. 2004. Systemtheorie und Gender. Das Geschlecht im Netz der Systeme. Wiesbaden: VS Verlag für Sozialwissenschaften.

West, C., and D. Zimmerman. 1987. Doing Gender. Gender and Society 1 (2): 125-151.

Wetherell, M. and N. Edley. 1999. Negotiating Hegemonic Masculinity: Imaginary Positions and Psycho-discursive Practices. Feminism and Psychology 9 (3): 335-356. 